\title{
James's Central Intelligence and the Deconstruction of Character
}

\author{
BY \\ Heide ZIEGLER*
}

Even if Virginia Woolf's well-known statement in * Mr Bennett and Mrs Brown * that in or about December, 1910 human character changed is primarily a personal proclamation, ${ }^{1}$ we can nevertheless detect an increasing uneasiness in the treatment of character at the beginning of the modernist age at large. Just as language tended to become a mode of self-expression rather than simply a means of referring to the denominated object, so doubts about the demarcation between 'inside' and 'outside' began to erode belief in character as a stable or substantial identity, a center of action. Yet even when, for the representatives of the modernist age, change in the perception of character meant a loss of character or at least the collapse of a stable self, the concept of character was only altered and not - as in postmodernist fiction - rejected altogether. The modernist change consisted in the substitution of character seen as function for character seen as substance. Postmodernist concepts of character, however, like Robert Jay Lifton's * protean man * or Leslie Fiedler's * new mutants, no longer assume an unchanging identity behind functional masks, identity being the logical prerequisite for the recog-

- University of Wurzburg.

REVUE FRANÇAISE D'ÉTUdES AMǴRICAINES 
nition of such masks. Instead, the idea of protean or mutant man presupposes no opposition between identity and change at all. The principle of change becomes absolute.

Historically, the change of character Virginia Woolf noted is as much the consequence of a loss of belief in a stable self as of a loss of belief in a stable society. Every development of character takes place only through the constant interplay of personal features and social circumstances. It is his awareness of this fact and of what he saw as the increasingly complex consequences of this interplay which constitutes the foundation of Henry James's concept of character. Whereas Virginia Woolf sought to rescue human character by saving it from the moral constrictions of society, James saw character as a process dependent on what, in the Preface to - The Lesson of the Master, $*$ he called * operative irony. ${ }^{2}$ This operative irony might be defined as a kind of utopian ideal of self-realization within the constricting framework of social values whose " reality " must, paradoxically, be asserted by the character himself :

There are decencies that in the name of the general self-respect we must take for granted, there's a kind of rudimentary intellectual honour to which we must, in the interest of civilisation, at least pretend. 3

James's characters are ironic precisely because they are fated to change out of their love for tradition and traditional values. Virginia Woolf's characters expand, but they do not - despite her protestation to the contrary - change. They are fated to become what, subconsciously, they have been from the beginning; they merely arrive at a consciousness of their unconscious qualities and capacities. In the course of encountering others their sensibility and awareness become directed towards themselves. If Virginia Woolf usually avoids employing first-person narration, it is because such a selfconscious point of view would falsely contain a character whose realm of becoming is determined by the energies of the unconscious. James, on the other hand, creates characters who expand only to the degree that they become aware of the danger of losing themselves, and who believe in communication, conceived as a traditional pattern, as a means of defining themselves.

James, therefore, sees character as a function, but not as a functional structure in the sense of, for instance, Jean Piaget, for whom personal traits are replaced by the influences of society and for whom 
character only constitutes itself as the locus of the constant intersection of those influences. James's ironic mediation between self and society precludes the assumption of character as substance. Instead, he deconstructs character by destroying the self as a stable identity in order to reconstruct it in the form of a central intelligence constantly endeavoring to transcend itself.

Since such central intelligences dominate James's most remarkable novels, they cannot be categorized as novels of character. In * The Art of Fiction s James argues against such an epithet altogether :

There is an old-fashioned distinction between the novel of character and the novel of incident which must have cost many a smile to the intending fabulist who was keen about his work. It appears to me as little to the point as the equally celebrated distinction between the novel and the romance - to answer as little to any reality. 4

James would not have wanted to call novels like The Portrait of a Lady, What Maisie Knew, or The Ambassadors novels of character, because the term struck him as not sufficiently inclusive. No Jamesian character could come to life without being involved in a series of incidents. 5 The implication is not that for James the concept of character was questionable, but rather that his belief in character as development, as a process of constant mediation between self and world, begs the question of its usefulness as an appropriate term for critical usage.

Thus the Jamesian character develops organically into the central intelligence, since the central intelligence, in responding to all the incidents of the novel, appears to offer an encompassing scope of worldliness, answering fully to any reality depicted by the novel. The question arises, then, whether the central intelligence is to be defined simply as a character endowed with properties that exceed the usual range, whether he is a character with a special narrative point of view, or whether, finally, he is a device to substitute for character as such, anticipating the postmodernist attempts to replace the character's identity with that of the narrator.

In his Aspects of the Novel, E.M. Forster claims « that most of human life has to disappear $₫ 6$ before James can achieve an aesthetic effect like the one produced in, for instance, The Ambassadors. This disappearance of human life Forster supposes to be a result of James's reducing the range of possible characters as well as of possible experience. Thus, he regards James's characters as inevi- 
tably maimed. However, Forster seems not to appreciate the fact that whenever James chooses to subject the incidents of a novel to the observation of a central intelligence, this very choice necessitates a restriction of characters as well as experiences. For the central intelligence's experience of other characters will be limited precisely insofar as he has to reckon with their actions, which for him constitute what we call the incidents of the novel. In fact, James's central intelligence is propelled into his role of observer through an increasing awareness of his inability to influence the novel's action.

But if the central intelligence limits the range of Jamesian character and experience with respect to quantity, he nevertheless extends it qualitatively. In the course of his development he leaves all the other characters behind. His increasing sensibility encompasses and thus transcends their respective limitations. Thus, while it would not be correct to say that the central intelligence becomes alienated from the other characters, since through his influence the understanding among all the other characters grows, it would be correct to say that he loses them. His achievement, therefore, becomes tainted by melancholy; it becomes a loss of the need to interact, a loss of the will to transcend those limitations of character and experience which for him, since he has already transcended them, no longer exist. Thus, although the central intelligence of James's novels supplies an ideal image of character, he does so at the cost of losing the traits of an individual character with the latter's implicit idiosyncrasies. Where a conventional character tends to be judged by the set of values he adheres to and by the degree to which he lives by those values, the Jamesian central intelligence has to be judged by the extent of his perception, and his morality resides in the conscientious exercise of his intelligence. The * publishing scoundrel * of The Aspern Papers, for instance, is immoral only because he is unwilling, given the call of a special human situation, to broaden his narrow perspective to include matters of the heart. His perspective as an obsessive editor is not immoral as such. Strether in The Ambassadors, on the other hand, is moral because he repeatedly succeeds in overcoming the bewilderment he has to face in a series of challenging situations. But the truth or, better, the true insights he arrives at remain much more precarious than those principles, which motivate the offensive conduct of Jeffrey Aspern's relentless pursuer. They are adequate only for the given situation and mirror the degree of perception with which Strether deals with it. Morality and truth, 
therefore, do not coincide, except as they are seen through the eyes of a central intelligence. Morality and truth are nothing but different aspects of life.

This inference can be corroborated when we compare the central intelligence with the ficelle as a special form of the Jamesian character. The ficelles in James's work are not minor characters, if their comparative significance be measured by, say, the number of pages devoted to each of them. Although some ficelles like Henrietta Stackpole in The Portrait of a Lady and Waymarsh can be identified as such by this standard, the same can certainly not be said, for example, of Maria Gostrey in The Ambassadors. Still, in the Preface to The Ambassadors, James defines Maria Gostrey as well as Waymarsh as ficelles, while interestingly distinguishing between the two by calling Waymarsh Strether's friend and Miss Gostrey - the reader's friend much rather. ${ }^{7}$ This friendship between her and the reader does not mean any disregard for the limits of the text (as a postmodernist reading of James's phrase might imply); instead, Miss Gostrey's function consists in helping to dramatize, in her encounters with Strether, what would otherwise have been nothing but \& the seated mass of explanation after the fact, the inserted block of merely referential narrative. $\$ 8$ Moreover, and even more importantly, Miss Gostrey proves to be the reader's friend by throwing into relief Strether's emotional and intellectual development through her active interest and unerring devotion. It is, in fact, precisely this devotion to Strether which makes her, after all, into a ficelle, that is, a person who already knows so much that she no longer has any need for development or self-assertion. She thus becomes a foil to Strether's endeavors to orient and situate himself within his unwonted Parisian context.

The use of the ficelle bears on the significance of the Jamesian character, since it renders superfluous, through the ficelle's dramatizing and mirroring faculties, the use of first-person narrator. James says, for instance, that he chose not to grant Strether in The Ambassadors the advantage of first-person narration, because as a third person Strether has to « keep in view proprieties much stiffer and more salutary than any our straight and credulous gape are likely to bring home to him. » It is through Miss Gostrey that this * straight and credulous gape $\gg$ on the reader's part can be averted. Thus, James can save Strether from « the terrible fluidity of self-revelation. » 9 Norman O. Brown, in speaking of the ancient Roman notion of cha- 
racter as carved mask, a persona (which accounts for the rigidity of the Roman ideal type), sees character as * magical and mechanical. 10 This definition seems to take up the * stiffer and more salutary » proprieties required by James, who describes the effect of Madame de Vionnet on Strether, * as half mythological and half conventional. "Madame de Vionnet is revealed to be the opposite of a person who would dissipate herself in the terrible fluidity of selfrevelation. The mythological and the conventional share the traits of internal organization as well as of ritualized repetition which, at their best, can constitute the framework for a life dedicated to the enhancement of human sensibility.

Narrative self-revelation, however, means the draining of energy without an opportunity for self-renewal and without an opportunity for improvement through the development of one's taste and the exercise of one's intelligence; for taste and intelligence rest on the faculty of restraint and, through restraint, on the possibility of re-cognition. Recognition, an emotional anamnesis which is a form of conscious withholding from present fulfillment, is one of the key words in James's fiction. When two Jamesian characters who have never met before experience a sense of recognition on their first encounter, they follow the call of a might-have-been which leads them, irresistably, into verbal exchanges over, as James would say, * charming * or * interesting, " that is, mythical as well as conventional matters. For James any true meeting of minds depends on the tacit acknowledgement of this might-have-been and thus on the repeated opportunity for dialogue which, in his fiction, needs to be dramatized in a series of scenes which serve the characters alternatively to reveal and to veil themselves, to demonstrate innocence as well as artfulness. To apply Brown's more pronouncedly structural terminology and call this mutual constitution of character mechanical as well as magical serves to underscore James's deconstructive amalgamation of myth and convention. The mechanics of social interplay reveal a magical quality whenever a character is deconstructed, that is, whenever a character is led, by another character, into Jamesian bewilderment in order to gain the opportunity of recovering the truth ever inherent in the encounter of the Other.

The conditions of this truth are historically, not individually, founded. * An occasion, s says Strether, * isn't the people. It's what has made the people possible. $>12$ The most responsive sensibility and the most acute intelligence only bring into focus different sets of 
traditional values. Thus, James's characteristic * international theme $>$ means nothing but that, through the heightening of sensibility and intelligence, he forces his characters to compare different sets of values in order to re-shape them for themselves. A character, therefore, can only constitute himself tentatively - as on the borderline between the experience of America and Europe. Since the irreconcilability of America and Europe, the new and the old, can never be experienced as an existential crisis by anyone who is thoroughly steeped in one or the other set of values, every such person, even the most perceptive, must remain a type. A Jamesian type, therefore, the effective equivalent of the ficelle, is not a flat character but a person who is never called upon to sacrifice cherished attitudes and opinions as a person caught between two cultures inevitably must. This is the reason why the type always carries an immediate advantage over the central intelligence, but why, at the same time, he is irresistably drawn to this central intelligence : he is fascinated by the latter's ability to learn through suffering.

For this suffering is redeemed by the saving grace of language. The ultimate reason why, for James, character becomes a central intelligence has its roots in the tension between the central intelligence's inability to participate in the novel's action and the compensatory powers of narration. James implicitly presupposes the hermeneutic ideal that human consciousness can understand the meaning of its own experiences, regardless of the fact that this meaning may at first be hidden and may have to be achieved through an act of $\alpha$ archeological s reconstruction - to apply a term of Michel Foucault. This act of understanding, however, is dependent on the symbolic order of language, because the self can never hope to discover its own roots save through the mediation of signs. For James this need of language as agent of mediation does not bespeak a schism between the self and reality but rather a means of objectifying the self. Thus, to achieve this objectification of the self through constant attention to language is the ultimate endeavor of every Jamesian central intelligence. This is what his taste and intelligence finally amount to : they make it possible to employ words so as to overcome the resistance that the world might present to the interpretation of \& real $\otimes$ things in terms of consciousness. The world, of course, always remains something to be reckoned with. It contains the permanent possibility of surprise which no method can bring under control. If the central intelligence seeks to anticipate developments and to influence them through language as symbolic action, he must inevitably fail 
to create the desired order because the world cannot be manipulated by language; language being but the vehicle of meaning, he can only interpret the world, that is, he has to consent to becoming the locus for the exfoliation of this meaning by substituting passivity for activity and by suffering the meaning of the world to speak through him.

By thus becoming the vessel of its worldliness, the Jamesian central intelligence unexpectedly transcends the limits of the text. He comes to represent the tension between a plot which closes off the text according to a preconceived pattern and the never wholly satisfactory significance of his own constantly deferred presence in the text. The central situation which dominates the Jamesian novel and which elicits what Edith Wharton calls \& centripetal incidents $>13$ is counteracted by the urgency of the central intelligence's search for meaning. This urgency gives to the text the status of a mere beginning, of a process toward judgement and evaluation beyond the limits of the text. Its ultimate aesthetics seem to consist in a constant striving for, and yet constant loss of, life. The very dramatization of circumstances and evocation of sensations which seem to turn every Jamesian discourse into a scene and every Jamesian locale into a stage, prepare the reader for the inevitable artificiality of every existential experience which is being presented as a text. When Strether in The Ambassadors spends a day in the country, he senses that the perfect atmosphere of the day, which he significantly equates with the atmosphere evoked for him by a Lambinet painting he had once wanted to buy, forms a complete textual pattern which, like the painting within its frame, is nevertheless confined to a particular place :

'The' thing was the thing that implied the greatest number of
other things of the sort he had had to tackle; and it was queer
of course, but so it was - the implication here was complete.
Not a single one of his observations but somehow fell into a place
in it; not a breath of the cooler evening that wasn't somehow
a syllable of the text. The text was simply, when condensed, that
in these places such things were, and that if it was in them one
elected to move about one had to make one's account with what
one lighted on.

The tightly plotted text, like a painting, may render an impression of perfect harmony, since all parts relate to each other in such a way as to seem to imply all possible interpretations as so many modes of pertinence. However, this harmony is static, and the central intelligence, in being the dynamic force of the novel, will disturb 
this harmony simply by entering it. When Strether sees a boat advancing round the bend of a river, containing a man who holds the paddles and a lady with a pink parasol, he still believes this to be \& exactly the right thing, 15 something that had been wanting in the picture. But on his detecting that the man and the lady are Chad Newsome and Madame de Vionnet, the harmonious text of this summer day is interrupted, since the dynamic relationship between the three characters explodes the frame of the picture, substituting explication for implication, development for simultaneity.

Thus, the central intelligence in James's novels represents the signifying intention of the text, transcending the merely psychological intention which might be ascribed to any fictional character. If the Jamesian novel is a vast and intricate system of correspondences, then it is the central intelligence that allows us to isolate from among these correspondences a sense of the possibilities of the future, as well as the need for a constant conversion of thought from static to dynamic. The preconceived plot of the Jamesian novel constrains the actual possibilities of the central intelligence as a character and reduces his function to that of commentary and exegesis; yet at the same time it provides the ideal conditions for an exercise of his intelligence in his attempt to transcend the constrictions of this very plot and for a refinement of his taste as an attrition of its overriding demands. The deconstruction of character in James's novels reveals a human possibility and turns it into a task: the development of the imagination as an instrument for understanding life. 


\section{NOTES}

1. Cf. Phyllis Rose, Woman of Letters : A Life of Virginia Woolf, (New York: Oxford University Press, 1978), p. 102.

2. Henry James, The Art of the Novel: Critical Prefaces, intr. Richard P. Blackmur, (New York and London: Charles Scribner's Sons, 1962 [1934]), p. 222.

3. Ibid., p. 222.

4. Henry James, The House of Fiction: Essays on the Novel, ed. and intr. Leon Edel, (London: Rupert Hart-Davis, 1957), p. 34.

5. Cf. Preface to The Portrait of a Lady, in James, The Art of the Novel pp. $42 \mathrm{f}$.

6. E. M. Forster, Aspects of the Novel, (New York: Harcourt, Brace, 1927), p. 228.

7. James, The Art of the Novel, p. 322.

8. Ibid., p. 321.

9. Ibid., p. 321.

10. Norman O. Brown, Love's Body, (New York: Vintage Books, 1966), p. 95.

11. Henry James, The Ambassadors, New York Edition, XXI-XXII, (New York: Charles Scribner's Sons, 1937 [1909]), XXI, 270.

12. James, The Ambassadors, XXII, $164 \mathrm{f}$.

13. Edith Wharton, - The Man of Letters, in: Henry James: A Collection of Critical Essays, ed. Leon Edel, (Englewood Cliffs, N.J.: Prentice-Hall, 1963), p. 33.

14. James, The Ambassadors, XXII, $253 \mathrm{f}$.

15. Ibid., p. 256.

No $17 \cdot \operatorname{MAI} 1983$ 